\title{
Subordination and Freedom: Tracing Anarchist Themes in First Peter
}

\author{
Justin Bronson Barringer
}

Southern Methodist University

First Peter seems an unlikely place to look for anarchist inspiration. In fact, at first glance it seems to offer support for the very sorts of domination that anarchists so adamantly oppose: governments over citizens, masters over slaves, and husbands over wives. Drawing on Petrine scholarship, historical insights, political philosophy, theology, and biblical exegesis, this paper will argue that, in fact, First Peter contains several anarchist themes. The paper shows that Peter advocates non-coercion, voluntary association, equality of all persons, and subversion of the powers that be. By examining some key debates in Petrine scholarship, the essay examines some relevant points of contention like debates over the meaning of Peter's use of the haustafeln tradition and proper translations of key Greek words related to government and submission/subordination before showing that the best interpretations point to something at least akin to anarchism in this text. Peter's concerns are moral and ethical as well as political and this essay weaves together all of those areas on inquiry to put forward a reading that offers a Christian anarchist ethic and political theology. Two millennia after it was written, Peter's epistle still offers a compelling vision for an alternative society, a society that embraces anarchist values and works to subvert the powers intent on maintaining their perceived control of the world.

\section{Introduction}

First Peter seems an unlikely place to look for anarchist inspiration. At first glance it seems to support the very sorts of domination governments over citizens, masters over slaves, and husbands over

How to cite this book chapter:

Bronson Barringer, J. 2018. Subordination and Freedom: Tracing Anarchist Themes in First Peter. In: Christoyannopoulos, A. and Adams, M. S. (eds.) Essays in Anarchism and Religion: Volume II. Pp. I32-I72. Stockholm: Stockholm University Press. DOI: https://doi.org/Io.I6993/bas.e. License: CC-BY. 
wives - that anarchists oppose. ${ }^{\mathrm{I}}$ This paper will examine whether, and to what extent, First Peter contains themes that inform an anarchist position. ${ }^{2}$ First Peter is a short letter attributed to the Apostle Peter (I:I), though its authorship is still contested by scholars. ${ }^{3}$ Likewise scholars argue about when exactly the letter was written, but most agree that it is written to address the persecution of Christians that was either already going on or was expected in the near future. Peter's first letter is addressed to exiles scattered throughout Asia Minor, perhaps people who had fled Jerusalem or Rome due to persecution. ${ }^{4}$

Peter is concerned about the welfare and the witness of his fellow Christians. First Peter in many ways reflects Jesus' words to be "wise as serpents and innocent as doves" 5 because the letter offers these Christ-followers advice about avoiding persecution,

I Peter's letter to "exiles" in this world exhorted early Christians to embody this movement toward anarchy as they adopted a certain way of being in the world, a way of being that would ultimately point to another, better world. It was by adopting non-coercion, voluntary association, and the equality of persons that these early Christ-followers put themselves in a place that necessarily subverted coercive hierarchies.

2 Jonathan Bartley, Faith and Politics After Christendom: The Church as a Movement for Anarchy (Milton Keynes: Paternoster Press, 2006), 8. Bartley suggests that in a post-Christendom world it is right to recognize "the church as a movement for anarchy." I believe Bartley is right, but I argue Peter had this vision in mind well before Christendom. It is anachronistic to call Peter's writing anarchist, but anarchist themes are found throughout his first letter. The themes that will be examined include non-coercion, voluntary association, equality of persons, and subversion of the powers that be, all for the sake of Jesus.

3 I am most persuaded by arguments for the traditional position that this letter was indeed written by Peter, so I will attribute it to him throughout this essay.

4 Craig Keener, The IVP Bible Background Commentary: New Testament (Downers Grove: InterVarsity, I993), 706. Christians were lumped together with other minority religions in the minds of many in the Roman Empire. Naturally they were directly linked to the Jews, and "Romans viewed Christians, like Jews, as antisocial" (706). However, they were also viewed with suspicion because they had superficial similarities with other despised religious sects like the cults of Isis and Dionysus. See also David L. Balch, Let Wives Be Submissive: The Domestic Code in I Peter (Chico: Scholars Press, I98I), 65-73.

5 Matt. IO:I6 
yet instructs them how to live courageous and moral lives in the face of slanderous accusations and oppressive violence precisely because they have faith in the Christian God.

This is a good place to mention definitions. I have little concern with the idea of "religion." Following William Cavanaugh, I would assert that "there is no such thing as a transhistorical or transcultural 'religion' that is essentially separate from politics," and that "the attempt to say that there is a transhistorical and transcultural concept of religion that is separable from secular phenomena is itself part of a particular configuration of power, that of the modern, liberal nation-state as it developed in the West." ${ }^{6}$ Rather, I am concerned to address the faith broadly called Christian. As for "anarchism", I have essentially adopted a combination of the definitions offered by Vernard Eller and Jacques Ellul later in the essay.

One of Peter's main purposes is, as Joel B. Green puts it, to answer questions such as: "What to do with Rome? What to do about Rome? What to make of Rome?"7 Green explains that "For Peter, of course, 'Rome' really was the issue: its sanctioned religions, its imperial and colonizing presence and practices, its world system, its matrices of honor and order." 8 Should they rebel? Should they acquiesce? Should they withdraw? Should they make compromises? Or, should they do something altogether different? Green then points out that "Peter understands that the problem is not about Rome per se, though, and so he refers to Rome not by its real name but as 'Babylon.' 'Babylon' was a cipher for a world power hostile to God, and, for Peter, this is what Rome had become." 9

In order to articulate the view that Peter's letter proposes several ideals compatible with anarchism, this essay will first offer some preliminary definitions of anarchism in general and Christian anarchism in particular by briefly surveying some of the relevant literature. The following section will then describe one of the key

\footnotetext{
${ }^{6}$ William Cavanaugh, The Myth of Religious Violence: Secular Ideology and the Roots of Modern Conflict (Oxford: Oxford UP, 2009), 9.

7 Joel B. Green, I Peter (Grand Rapids: Eerdmans, 2007), I.

8 Ibid., I.

9 Ibid., I.
} 
interpretive considerations: the ancient household code, a literary form Peter uses in his letter to instruct his readers. From there the essay will turn to the specific themes Peter addresses that correspond with an anarchist vision for society, including non-coercion and voluntary association, equality of persons, and how each of those empowers individuals and communities to subvert the powers. The essay will conclude by arguing that Peter's vision for this alternative sort of society is wrapped up in his understanding that it is not those who seek power who will ultimately shape the world, but those whose humility is evident that will make this reality, inaugurated by Jesus, manifest in the world until it is someday likewise consummated by Jesus.

This essay argues that Peter proposes an unconventional vision whereby oppressive power structures are subverted and the oppressed are freed when those with little power, counterintuitive as it may seem, subordinate themselves to the powers that be. While this argument may not be particularly popular, it is not unheard of amongst self-proclaimed anarchists and those offering anarchist-friendly theologies, but it is uncommon enough that it is worth briefly exploring here before delving into the specifics of Peter's own arguments for subordination as a subversive practice.

Tolstoy argues, in the opening of his short essay "On Anarchy," that "[anarchists] are mistaken only in thinking Anarchy can be instituted by a revolution. . . But [anarchy] will be instituted only by there being more and more people who do not require protection from governmental power, and by there being more and more people who will be ashamed of applying this power." ${ }^{\circ}$ Peter instructs his readers to subordinate themselves rather than attempt a revolution or rebellion. His readers, largely, did not have the option to seek government protection anyway, but Peter's case is that they did not require it because they put their trust in the Lord. Nevertheless, they were able to shame oppressive powers by living morally upright lives.

Io Leo Tolstoy, "On Anarchy" in Pamphlets Translated from the Russian. Accessed on December 30, 2013 at https://archive.org/stream/ pamphletstranslootolsgoog\#page/n250/mode/Iup 
Late theologian and ethicist John Howard Yoder talks about "revolutionary subordination" ${ }^{\mathrm{II}}$ as the way in which Christians work for social change (including, problematically, the subordination of women to men, which I will anyway return to below). ${ }^{\mathrm{I}} \mathrm{He}$ makes the important observation that something in the Christian religion had already prompted subjugated classes to embrace freedoms that they had never known before. ${ }^{\mathrm{I} 3}$ Thus they were tempted to a certain unruliness that would, in its context, be shameful because women and slaves were expected to show certain decorum, and presumably doomed to failure. The peculiar revolutionary element, for Yoder, is that, "after having stated the call to subordination as addressed first to those who are subordinate already", those who have embraced this subordination "then

${ }^{\text {II }}$ It is worth noting that in Yoder's personal life he greatly abused his own power, which may cause some to question his work on the subject. I think this is fair though I contend that the value of his insight stands alone. The idea of "revolutionary subordination" is particularly problematic when read in light of Yoder's preying on female subordinates and often sexually assaulting them. It might also be said that "revolutionary" is strong of a term as the moves envisioned by writers like Peter may have smaller and more gradual societal changes in mind, which seems to fit well with Jesus' parable of the mustard seed. Also see Yoder quote from Ibid., I 86. Rightly understood though, it is the powerful, it seems in Yoder's thought, though clearly not in his life, who ought to find occasions to subordinate themselves, just as Jesus did. That is revolutionary. For an extended account of Yoder's sexual predation see Rachel Waltner Goosen, “'Defanging the Beast': Mennonite Responses to John Howard Yoder's Sexual Abuse" in Mennonite Quarterly Review, No. 89, January 20I5. http://www.bishop-accountability.org/ news 5/20I 5_OI_Goossen_Defanging_the_Beast.pdf

${ }^{12}$ Feminist scholars, such as Elisabeth Schüssler Fiorenza have taken particular exception to Yoder's account. And they are probably right inasmuch as only expecting women to submit is indeed problematic and leads to abuse. The appropriate change only happens in the church and society when free men submit themselves to slaves and women, which may have been precisely the case in I Peter 5:5. This works its way into mutuality and thus erodes oppressive systems, not so much abolishing them immediately. Note Elisabeth Schüssler Fiorenza, Bread Not Stone: The Challenge of Feminist Biblical Interpretation (Boston: Beacon Press, I995), 82-83.

${ }^{13}$ John Howard Yoder, The Politics of Jesus (Grand Rapids: Eerdmans, I994), I73. 
go on to turn the relationship around and repeat the demand, calling the dominant partner in the relationship to a kind of subordination in turn." " ${ }^{4}$ For Yoder, it is precisely because "the call to subordination is reciprocal [that it] is once again a revolutionary trait." ${ }^{15}$ Yoder goes on to write:

The Christian is called to view social status from the perspective of maximizing freedom. One who is given an opportunity to exercise more freedom should do so, because we are called to freedom in Christ. Yet that freedom can already become real within one's present status by voluntarily accepting subordination, in view of the relative unimportance of such social distinctions when seen in the light of the coming fulfilment of God's purposes. ${ }^{16}$

In other words, Yoder recognizes that what Peter is doing here is calling Christians to continue to move toward freedom whenever possible, but to also keep in mind that their freedom is tied up in the freedom of every other person. It is by choosing to live in thoughtfully restrained freedom that Christians are able to offer a compelling witness to the world around them, thus exhorting their fellow humans to join this way of Jesus that will increase all people's freedom, rather than uphold the structures which oppress many while affording autonomy to only a few.

Some might question whether this approach really "works," but this question seems foreign, or at least secondary to Peter and to the other New Testament writers. They simply are not utilitarian enough because they trust that ultimately God will set all things right even if humans fail. However, this does not mean they are not concerned with human thriving: the New Testament writers articulate a vision for a different sort of society, a society within society, lived out in the political community called the church. The New Testament writers offer us "reason to hope that the loving willingness of our subordination will itself have a missionary impact," ${ }^{17}$ but our hope lies not in our own ability to make history turn out right, but in the fact that our witness will be used by

\footnotetext{
${ }^{14}$ Ibid., I77.

I5 Ibid., I77.

${ }^{16}$ Ibid., I 82.

${ }^{17}$ Ibid., I 85 .
} 
God's Spirit to challenge domineering systems to forsake their oppressive ways in exchange for the upside-down Kingdom where it is the servants who exemplify honourable behaviour. Again Yoder writes:

[Jesus'] motto of revolutionary subordination, of willing servanthood in the place of domination, enables the person in a subordinate position in society to accept and live within that status without resentment, at the same time that it calls upon the person in the superordinate position to forsake or renounce all domineering use of that status. This call is then precisely not a simple ratification of the stratified society into which the gospel has come. The subordinate person becomes a free ethical agent in the act of voluntarily acceding to subordination in the power of Christ instead of bowing to it either fatalistically or resentfully. The claim is not that there is immediately a new world regime which violently replaces the old; rather, the old and the new order exist concurrently on different levels. It is because she knows that in Christ there is no male or female that the Christian wife can freely accept that subordination to her unbelieving husband which is her present lot. It is because Christ has freed us all, and slave and free are equal before God, that their relationship may continue as a humane and honest one within the framework of the present economy, the structure of which is passing away. ${ }^{18}$

With this basic understanding of the way voluntary subordination might be a subversive practice (an admittedly at first surprising but actually fairly widespread Christian anarchist perspective) ${ }^{\mathrm{Ig}}$, it is now appropriate to define anarchism and anarchy for the purposes of this essay then turn to the way in which Peter lays out his anarchist vision of subordination and freedom.

\section{Defining Anarchism and Christian Anarchism}

Defining anarchism (the ideology) and anarchy (the aim) is sometimes difficult because historically they have had a wide range of definitions, and the words themselves are loaded. David Miller

${ }^{18}$ Ibid., I 86.

19 See Alexandre Christoyannopoulos, Christian Anarchism: A Political Commentary on the Gospel (Exeter: Imprint Academic, 20I I), chapter 4 
writes: "Of all the major ideologies confronting the student of politics, anarchism must be one of the hardest to pin down. It resists straightforward definition." ${ }^{20}$ Anarchy is often misunderstood as chaos, "a black monster bent on swallowing everything; in short, destruction and violence," ${ }^{21}$ and this has led many to dismiss the idea of Christian anarchy out of hand, since the Christian God is not a God of disorder, but a God of peace. ${ }^{22}$ The word "anarchy" was originally used pejoratively to describe English and French revolutionaries, ${ }^{23}$ and many people still use the term in a derogatory fashion, as if it were simply synonymous with chaos. Again Miller writes: "The prevalent image of the anarchist in the popular mind is that of a destructive individual prepared to use violent means to disrupt social order, without having anything constructive to offer by way of alternative - the sinister figure in a black cape concealing a stick of dynamite." ${ }^{24}$ However, as this essay will demonstrate this is neither the sort of movement that Peter, nor contemporary Christian anarchists have in mind.

Moreover, the image Miller describes is still common in the minds of many Christians, who therefore see anarchy as incompatible with Christianity. Besides, secular anarchists argue "Christianity has produced about as hierarchic a structure as can be, and anarchism not only rejects any hierarchy but is also often fervently secular and anti-clerical." ${ }^{25}$ Both views are unfortunate because the Bible, particularly the New Testament, contains many themes akin to anarchy. Similarly, many theologians and Christian leaders from Tertullian to Barth and Tolstoy to Dorothy Day, have espoused a range of anarchist-friendly theologies.

${ }^{20}$ David Miller, Anarchism (London: JM Dent, I984), 2.

2г Emma Goldman, "Anarchism: What It Really Stands For" in Anarchism and Other Essays (New York: Mother Earth Publishing Association, I9I0). Accessed on November 2, 20I3 at http://dwardmac.pitzer.edu/ anarchist_archives/goldman/aando/anarchism.html

22 I Cor I 4:33.

${ }_{23}$ Nicolas Walter, “About Anarchy” in Howard J. Ehrlich, Carol Erlich, David DeLeon, and Glenda Morris eds., Reinventing Anarchy: What Are Anarchists Thinking These Days? (London: Routledge \& Kegan Paul, I979), 42 .

24 Miller, 2.

25 Christoyannopoulos, I. 
While most anarchists agree that society can and should function without the rule of government, there are disagreements about what shape an alternative society would take. ${ }^{26}$ Anarchists ranging from Kropotkin and Goldman, to Randal Amster and Mohammed Bamyeh, however, all recognize the themes this essay notes in Peter's first epistle, namely non-coercion, voluntary association, equality of all persons, and subversion of the powers that be as central to a future anarchist society. ${ }^{27}$

${ }^{26}$ John P. Clark, "What is Anarchism?" in J. Roland Pennock and John W. Chapman, Anarchism: Nomos XIX (New York: New York University Press, I978), 5. Clark's essay concisely yet thoroughly explains many variations within anarchist thought.

${ }_{27}$ Peter Kropotkin defines anarchy as "the name given to a principle or theory of life and conduct under which society is conceived without government - harmony in such a society being obtained, not by submission to law, or by obedience to any authority, but by free agreements concluded between the various groups, territorial and professional, freely constituted for the sake of production and consumption, as also for the satisfaction of the infinite variety of needs and aspirations of a civilized being" (Emphasis mine). Peter Kropotkin ed. Marshall Shatz, Conquest of Bread and Other Writings (Cambridge: Cambridge University Press), 233. Emma Goldman defines anarchy as "The philosophy of a new social order based on liberty unrestricted by man-made law; the theory that all forms of government rest on violence, and are therefore wrong and harmful, as well as unnecessary" (Emphasis mine). Emma Goldman, "Anarchism: What It Really Stands For" in Anarchism and Other Essays (New York: Mother Earth Publishing Association, I910). Accessed on November, 2 at http://dwardmac.pitzer.edu/anarchist_archives/goldman/ aando/anarchism.html. Randall Amster argues, "Anarchism is at its root a philosophy and set of practices based on the premise that people can and should act from a place of freedom from domination and coercive force. . . Our self-interest is wholly bound up with the interests of everyone else, making anarchism in its full dimensions a theory of radical egalitarianism as much as one of individual autonomy" (Emphasis mine). Randall Amster, Anarchism Today (Santa Barbara: Praeger, 20I2), 2. Bamyeh is, perhaps ironically, not as forceful in his definition of anarchy at least as it relates to coercion, yet he still seems interested in understanding anarchy as a society where coercion is unnecessary. He writes, "[Anarchy] does in fact signify order, but one of a very specific type: in its most pristine and developed forms anarchy is unimposed order. In a less developed but still noble enough form, anarchy is a quest for unimposed order - that is, order supported by the minimum necessary use of coercion" (Emphasis mine). Mohammed A. Bamyeh, Anarchy as Order: The 
One particular variety of anarchism is specifically Christian. One way to define Christian anarchy is to begin with a Biblical understanding of the powers that be, which are said to be more impressed with the god of this age than with the God of eternity. ${ }^{28}$ Vernard Eller offers a helpful explanation of the powers and a useable definition of Christian anarchy. He writes,

For us, then, 'archy' identifies any principle of governance claiming to be of primal value for society. 'Government' (that which is determined to govern human action and events) is a good synonym - as long as we are clear that political arkys are far from being the only 'governments' around. Not at all; churches, schools, philosophies, ideologies, social standards, peer pressures, fads and fashions, advertising, planning techniques, psychological and sociological, theories - all are arkys out to govern us. 'Anarchy' ('unarkyness'), it follows, is simply the state of being unimpressed with, disinterested in, skeptical of, nonchalant toward, and uninfluenced by the highfalutin claims of any and all arkys. And 'Christian anarchy' . . . is a Christianity motivated by 'unarkyness.' ${ }^{29}$

Christian anarchy, according to Eller, is not about bullish rebellion, but it is a revolution of humble, lamb-like subordination - yet it is still a revolution..$^{\circ}$ It is about example, particularly about Christians embodying the example of Christ, neither being drawn to places of power, nor giving the powers special concern, but always being faithfully obedient to the Father. ${ }^{3 \mathrm{I}}$

History and Future of Civic Humanity (Lanham: Rowman \& Littlefield Publishers, 20I0), 27.

${ }^{28}$ The Bible tells Christians that "our struggle is not against flesh and blood, but against the rulers, against the authorities, against the powers of this dark world and against the spiritual forces of evil in the heavenly realms" (Eph 6:I2). If the struggle is indeed against the powers and rulers, the "archys," then to say Christians are anarchist seems to make perfect Biblical sense. See Luke I 2:I I, Eph 6:I 2, Col 2:I 5, I Cor I 5:24.

29 Vernard Eller, Christian Anarchy: Jesus' Primacy Over the Powers (Grand Rapids: Eerdmans, I987), I-2.

30 Christoyannopoulos discusses this peculiar kind of subversive subordination advocated by many Christian anarchists in Christian Anarchism, chapter 4 .

${ }^{31}$ Eller, 3. "For Christian anarchists, then, the goal of anarchy is 'theonomy' the rule, the ordering, the arky of God. At this idea, of course, the world rises up to insist that the arky of God is just as impositional as (if not 


\section{Haustafeln as a Literary-Rhetorical Tradition ${ }^{32}$}

A primary interpretive consideration for understanding I Peter is the hortatory form of the ancient household codes or Haustafeln, 33

more so than) any other arky that might be named. But Christians say $\mathrm{NO}$ - and that on two counts. First particularly as God has been revealed in Jesus Christ, the style of his arky is not that of imposition but of the opposite, namely, that of the cross, the self-givingness of agape-love. And second, God's arky, his will for us, is never anything extraneous to ourselves but precisely that which is most germane to our true destiny and being. . . Rather than a heteronomous imposition, God's arky spells the discovery of that which is truest to myself and my world."

${ }^{2}$ There is a longstanding debate, represented by David Balch and John Elliott, about whether relevant sections of I Peter are best understood in the Haustafeln or Oikonomia tradition. The former is understood as specific codes that individuals should follow, whereas the latter is more about the way the leader of the house manages everyone in the household. While there is merit to delineating the debate in this way, it is largely a distinction without much difference. Overall, I am satisfied with the use of Haustafeln language, though the one area where the Oikonomia language is helpful is in the recognition that Peter is not interested in mere capitulation to societal norms, that is the particular codified duties that society laid on each person; he is instead interested in reshaping those norms over time. I will thus stick to the more common language of Haustafeln, while on occasion noting the value of contributions from scholars like John Elliott. What is important in this debate is the extent to which I Peter articulates either resistance or conformity of Christians to surrounding society. David G. Horrell does a good job of describing this debate, while also suggesting a reading closer to mine, one that allows for "conformity and resistance" to be held in tension. David G. Horrell, "Between Conformity and Resistance: Beyond the Balch-Elliot Debate Towards a Postcolonial Reading of First Peter," in Reading First Peter with New Eyes: Methodological Reassessments of the Letter of First Peter, edited by Robert L. Webb and Betsy Bauman-Martin (New York: T\&T Clark: 2007), I I I-I 43.

33 Philippa Carter, The Servant-Ethic of the New Testament (New York: Peter Lang, I997), 87. "The Haustafeln texts in the New Testament have often been criticized as examples of how early Christianity capitulated to social institutions and mores that were burdensome for many people. I Peter is perhaps most susceptible to such a critique." It is also worth noting that while Peter's use of the form does not make up the whole letter, it does shape the content of other sections of his exhortations. For instance, Troy Martin suggests that "In 5:I-5 the community groups of elders and young men are even substituted for these [husband/wife, father/child, slave/master] pairs" commonly found in ancient household 
and the way Peter modifies the form for his purposes. The Haustafel was a code that "Stoic and other philosophers commonly used ... to delineate proper relationships with others." 34 The household code tradition did not begin with the Stoics though: "Plato and Aristotle, as well as other Greek political theorists, were interested in the relation between the 'city' and the 'house." "35 Peter, too, is interested in this connection; he first discusses his readers' relationship to the rulers of the wider society in $2: \mathrm{I}_{3}$ before he moves on to concerns in the home in 2:I8.

Aristotle and others were concerned about authority and subordination in relationships between husbands and wives, fathers and children, and masters and slaves because they believed that in order for society to function properly people had to fit into their natural place in the home or society would become corrupt and chaotic. ${ }^{36}$ Thus it makes sense that these codes had such widespread use and immense importance in Greco-Roman political theory, and furthermore why "Any group accused of upsetting proper subordination in the household would be criticized by those charged with maintaining the constitution [that is order in society]." ${ }_{77}$ Elliott seems to acknowledge this, but argues that I Peter's concern has more to do with internal cohesion among the church, and the distinct identity of Christians than conforming to societal expectations regarding order. ${ }^{38}$

Thus, the Haustafel form was enticing to minority religious groups attempting to find ways to interact with society because "slandered religious groups sometimes adopted these codes to demonstrate that their groups actually supported the values of the Roman society; this demonstration was important in combating persecution." ${ }^{39}$ If part of Peter's purpose in writing was

codes. In Troy W. Martin, Metaphor and Composition in I Peter (Atlanta: Scholars Press, I992), I 27.

34 Keener, 7I3.

35 Balch, I 5 .

36 Ibid., 6I.

37 Ibid., 6I.

${ }^{8}$ John Elliott, I Peter: A New Translation with Introduction and Commentary. Anchor Bible Commentary. (New York: Anchor/Doubleday, 2000), 505-5II.

39 Keener, 7I3. 
to demonstrate that Christians did indeed have a concern for the common good, and that they could indeed accept many Roman values, then it makes sense that he would adopt this form as a way to help protect his readers from undue persecution.

Of course, Peter had this purpose in mind, but only to a degree. ${ }^{\circ} \mathrm{He}$ wrote to help Christians avoid unnecessary persecution, while preparing them for the near inevitable persecution they will experience, ${ }^{4 \mathrm{I}}$ but more importantly Peter turns the form on its head to express truths about the Kingdom of God. ${ }^{42}$

The emphasis in many Haustafeln was on those with relative power. ${ }^{43}$ Yet, Peter gives more attention to wives and slaves, as well as ordinary citizens. Peter uses the code to express mutuality, ${ }^{44}$ a fundamental departure from patriarchal societal expecta-

$4^{\circ}$ Elliott argues that in fact "such an 'accommodating' and conformity-urging aim of the code material is thoroughly incompatible with exhortation of I Peter as a whole, which urges 'holy nonconformity, (I:I4-I7)" (Elliott 509). However, Elliott seems to concede on $5 \mathrm{IO}$ that there is nothing wrong with conformity inasmuch as it "is possible without compromise of one's loyalty to God." In other words, Elliott does not provide sufficient evidence that Peter might not have had in mind both of what Horrell calls "conformity and resistance."

4I See Green, 7I-72.

${ }^{42}$ Horrell, referring to Scott, notes that for instance, that there are "many diverse ways in which subordinates express and practice their resistance to oppression, in what he calls 'the immense political terrain that lies between quiescence and revolt'” (Horrell, I I 8). I am suggesting that the kingdom of God occupies this broad terrain.

43 This does not necessarily mean that the powerful were always mentioned first (Green, I64), only that they were treated as individual moral agents as opposed to those under their "rule" who were only told to obey, usually without further exposition.

44 Perhaps the mutuality here is implicit because of the mention of Sarah and the debate over who listened to whom in her marriage. (See Discovering Biblical Equality, 23Iff [esp. 234-235]). Also, note his argument for equality in marriage on 237. "When addressing those without power," notes Peter H. Davids, the apostle Peter "does not call for revolution, but upholds the values of the culture insofar as they do not conflict with commitment to Christ. He then reframes their behavior by removing it from the realm of necessity and giving it a dignity, either that of identification with Christ or of identification with the 'holy women' of Jewish antiquity. When speaking to the ones with power, however, he asks them not to use their power, but to treat those they could dominate as their equals - for in fact they are." (Peter H. Davids, "A Silent Witness 
tions. According to Boring, "It is striking that when the Haustafel enters the Christian stream, even though the patriarchal order continues to be presupposed, instruction is given in terms of mutuality and not merely hierarchy. . . In the Christian literature, slaves, women, and children are addressed as persons in their own right, not merely as subjects to masters, husbands, or fathers." 45 Balch writes:

Aristotle mentioned masters, husbands, and fathers before slaves, wives, or children. . . and addressed only the male - the master, husband, and father. In the NT [New Testament], however, the wives are addressed, and this is done before the exhortation of husbands. Slaves are addressed before masters in Colossians (masters are not exhorted in I Peter). The NT writers emphasize the subordinate members who were in a difficult social situation. . . Slaves and wives are addressed first by these early Christian moralists because they were the focus of an intense social problem between the church and Roman society. Romans frowned on their wives and slaves being seduced by bizarre foreign cults, and this led the author of I Peter to address the household code to those who were the focus of the tension. ${ }^{46}$

Although Balch's recognition of the differences between Aristotle's and the New Testament writer's use of the form is significant, his assessment is lacking. Peter addresses these folks to dignify them inasmuch as he makes claims about their ability to lead folks from pagan idolatry into relationship with God. In other words, as Horrell puts it, "The weak also exercise agency and power though the multifarious means by which they resist their domination, whether in hidden or overt ways," 47 a fact that Peter seems to be acknowledging, at least implicitly, through his instructions to them. While wives and slaves were occasionally mentioned in other Haustafeln, they were only told how to act without any justifying rationale. Peter exhorts wives precisely because they have

in Marriage" in Discovering Biblical Equality, eds. Ronald W. Pierce and Rebecca Merrill Groothuis - Downers Grove, IL: IVP Academic, 2005, p. 238.)

${ }_{45}$ M. Eugene Boring, I Peter (Nashville: Abingdon, I999), 106.

${ }^{46}$ Balch, 96-97.

47 Horrell, I I 8. 
the influence to win over their unbelieving husbands. Peter is not only making claims about their moral agency, but declaring their ability to lead their husbands into right belief.

Likewise, Peter is empowering slaves by using them as an example for all Christians. Peter's use of this form of ethical instruction itself bolsters the actual content of his exhortation. It serves at once to make it appear as if Christians fit into their society, and to call them into a better, alternative society. His instructions are not about keeping people in their place, but freeing them to love more fully. This ought to be understood as a uniquely anarchist position because it does not rely on any sort of paternalistic account of a better society whereby one group lifts another out of poverty or the like, rather it is a simple rejection of static hierarchies in favour of communities that are mutually empowering. Of course, in the short term Peter seems to be advocating for his readers to live in a particular way within the current hierarchy, all the while holding on to the hope that God will use their witness to create a more just and mutual society in which fluid hierarchies are more accepted..$^{8}$ This, then, ultimately suggests a rejection of the authority of the powers that be because the subordinate persons were no longer subject to them, but rather subject to the Lord.

As Randall Amster writes, "The rejection of authority is the sine qua non of anarchism. In this view, the imposition of power through force, coercion, domination and oppression is both unconscionable and untenable. . Anarchism challenges claims to authority that are vested with the enforcement power of the state." ${ }_{9}$ Therefore, Peter's vision as envisioned in this epistle, particularly his use of the Haustafeln form is anarchistic inasmuch as it does not seek to reform the powers and authorities as much as it seeks to see them abolished in this new society that is the church. ${ }^{\circ}$

$4^{8}$ See Horrell, I 20-I 2 I.

49 Randall Amster, Anarchism Today (Santa Barbara: Praeger, 2012 ), 6.

50 Peter is not interested in destroying the emperor as a person, since he does after all say that his readers ought to honor the emperor, rather he is interested, it seems, in the slow erosion of oppressive institutions including the position of emperor itself. One can honor the person, while believing that the office is unnecessary or even oppressive. I take this to mean that we are to honor people in places of power simply because they are people. We are not to show them special honor, and therefore we can 
Amster continues by offering some helpful headings in his chapter "Contemporary Anarchist Thought," which suggest a number of interconnected themes which collectively make up anarchy including several found in I Peter, such as "Anti-authoritarianism, "Voluntarism", "Mutualism", and "Egalitarianism." ${ }^{5}$ The anti-authoritarianism he describes is not against people asserting expertise in a particular area, but against someone moving beyond that area of expertise to force their authority on others. Amster explains that:

As it turns out contemporary anarchism is nuanced enough in its values to narrow its anti-authoritarianism to those exercises of power that are rigid, reified, and imposed, but not necessarily those that are present in healthy communities grounded in equality and respect. In an anarchist society, someone with expertise may well represent an authority in a certain sphere, without then asserting his or her power in another sphere. ... The critical factor for anarchists is that "the advice of an expert should only be accepted on the basis of voluntary consent," meaning that the acceptance of authority in any particular matter rests with the recipient and not the person or group asserting it. ${ }^{52}$

Peter, it seems, is arguing for this sort of society in the church. He allows for expertise to be shared among everyone in the community. In the very writing of the epistle, Peter is sharing his expertise as an authority, while suggesting that the response to that authority must not be coerced and likewise that the authority may move from person to person as the situation demands. ${ }^{53}$

hope for, and indeed expect, the abolition of all governments as each person confesses Jesus as Lord.

${ }_{51}$ Amster, 6, 8, 9, and I2.

52 Ibid., 7. Amster quotes Peter Marshall, Demanding the Impossible: A History of Anarchism (New York: Harper Perenial, 2008), 43.

${ }_{53}$ Amster's brief discussions on mutualism and egalitarianism likewise reflect Peter's own exhortations. Amster, for instance, writes: "Freed from compulsion, people learn to act at least in part for the common good, since there exists an undeniable recognition of the necessity of human community and sociality" (Ibid., 9), which echoes Peter's words in 2:I 5-I6 where is exhorts his readers to do good and avoid evil precisely because they have the freedom to do so. Like Peter, Amster sees egalitarianism (equality of persons) as an outcome of anti-authoritarianism, 


\section{Non-coercion and Voluntary Association}

Anarchists from a variety of traditions ranging from early thinkers like Kropotkin to modern scholars like Randall Amster have offered defences of non-coercion and voluntary association as foundational to their understanding of anarchism. In the Christian anarchist tradition in particular most expositors have tended to be pacifists as Ellul articulates when he writes that anarchy is "an absolute rejection of violence." ${ }_{54} \mathrm{He}$, like Peter, seems to do so on principle, but without losing sight of the potential for noncoercion to effect change. ${ }^{55}$ This is reflected in Peter's exhortations to wives, because it is their disciplined subordination, not an attempt at coercive rebellion, which Peter argues may lead their husbands in a shift of attitudes and actions.

Likewise, his more general exhortation to the whole Christian community to "Live such good lives among the pagans that, though they accuse you of doing wrong, they may see your good deeds and glorify God on the day he visits us" (2:I2) suggests that it is through living morally persuasive lives that people are won over to a particular group. Peter desires that people freely choose Christianity because they have been around those who have "tasted that the Lord is good" $(2: 3)$.

This is also reflected in Peter's opening line when he calls his

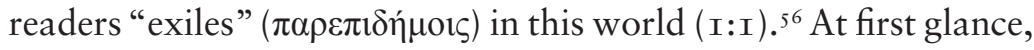

volunteerism, and mutualism. Amster writes: "An anarchist social order that eliminates coercion and domination promises to cultivate self-governing individuals who exhibit voluntary behaviors that are often mutually beneficial, ideally creating a horizontal network of productive enterprises and self-managing communities that could subsume the material and emotional necessities of life" (I2). This seems to reflect Peter's words in 4:8-Io in which he exhorts readers to love one another, offer hospitality, and share their gifts with others for the sake of the good of the whole community.

54 Jacques Ellul, Anarchy and Christianity (Grand Rapids: Eerdmans, I99I), Ir. See also Christoyannopoulos, Christian Anarchism, chapter I.

55 Ellul argues that disciplined nonviolence is often more effective in this regard than violence.

${ }^{56}$ Peter also uses similar language in 2:I I . It seems to suggest that Christians are not to demonstrate loyalty to any given nation or government. It is worth noting that Balch and Elliot differ on whether this term is a metaphorical one or a literal one. 
such a term seems to evoke images of coercion, as one rarely goes into exile on one's own accord. Yet, this is precisely the paradox of Christian faith. In spite of the impending persecution in their view, ${ }^{57}$ Peter's audience chose to join a movement that rejected the use of coercive force, and advocate extreme avoidance of such force by encouraging its members to favour places of lowliness rather than power. The witness of the community and their keryg$m a$, a Greek word that is best translated as proclamation, that Jesus had indeed overcome the most oppressive forces of all, sin and death $(\mathrm{I}: 3)$, was sufficient to draw people to the faith. Peter's use of the word $\pi \alpha \rho \varepsilon \pi 1 \delta \eta \mu$ is is indicative of both his belief in the attractive power of God's Spirit, inasmuch as people chose to take on the lowly position of exiles because they were persuaded by the beauty and goodness of Christian faith, and the basis for his later exhortations regarding the church's peculiar witness, as those who have become exiles in this world, of equality of persons and subversion of the powers.

Near the end of the letter, Peter offers an admonition to church leaders. Verses 5:I-5 are a return to the form of the Haustafel. Once again Peter co-opts the form to undermine conventional conceptions of authority; leadership in the church is not about coercive power, but example..$^{58}$ Likewise, and totally foreign to the Greco-Roman world, while it is true that "Peter advocates submission to the ruling elders [5:I]" it is important to note that "he also urges - against Greco-Roman society's ideals - mutual humility [5:5]." 59

Peter addresses leaders as a fellow elder. This is important because "Whatever hierarchical mode of thinking might be discernible in Peter's self-representation or in his talk of 'elders' is vacated by. . . Peter's refusal of special privilege by locating himself as an

57 This is reflected not only in Peter's letter, but in Christ's own words. "If they persecuted me they will also persecute you" (John I 5:20).

${ }^{5}$ There is not adequate space to explore this in this essay, but leadership by example is found throughout Peter's letter, both explicitly and implicitly. Christ is the example for all (2:2I). Peter is the example for his readers, particularly the elders $(5: \mathrm{I})$. Wives are examples for their husbands $(3: \mathrm{I})$. Shepherds are examples for their flocks $(5: 3)$.

59 Keener, $72 \mathrm{I}$. 
elder alongside other elders.” ${ }^{60}$ Though Peter has already identified himself as an apostle (I:I), "Additional evidence that, in instructing his audience, Peter is not exercising conventional authority is his apparent refusal to distribute directives simply on the basis of his apostolic office." ${ }^{61}$ Peter voluntarily humbled himself, relying not on his office for authority in the community, but on his communion with local church leaders, and on his experience as a witness ( $\left.\mu \alpha \alpha_{\rho} \tau \varsigma\right)$ testifying to Christ's sufferings.

Peter's own conduct implores church leaders to humble themselves and view their position not as an opportunity to lord power over others, but as a chance to use their gifts in service. In $5: \mathrm{I}-3$, those revered as leaders are counselled to live in exemplary fashion, and charged with the care of their congregations.

Peter applies the language of shepherding to church leaders. ${ }^{62}$ As Keener notes, "The image of a 'shepherd' is that of a concerned guide, not of a severe ruler," ${ }_{33}$ an image that hearkens back to Peter's identification of Jesus as shepherd and overseer (2:25). It is to be a ministry of example rather than an exercise of dominion $(5: 3)$.

The metaphor is then extended, and qualified, in light of the fact that every member of the church is a sheep under the care of the "Chief Shepherd" (5:4). This is further evidenced in the next verse as all members of God's household are exhorted to wear the same clothing of humility toward one another (5:5), as sheep all wear the same warm wool. It is not coercion that binds the Christian community, but a common humility.

It is also striking that Peter explicitly offers the elders the choice to "serve as overseers," rather than do so because they are obligated $(5: 2)$. It is not societal pressure, nor money, nor ego that

\footnotetext{
60 Green, I64.

6r Ibid., I64.

62 John 2I:I6. See Everett Ferguson, The Church of Christ: A Biblical Ecclesiology for Today (Grand Rapids: Eerdmans, I996), 319. This language is perhaps reminiscent Peter's own experience with Jesus when Jesus gave Peter the charge to shepherd Jesus' sheep. Ferguson notes, "The work of shepherds is in looking after sheep - protecting them, leading them to water and pasture, caring for their injuries, seeking them when lost" (32I).

63 Keener, 720-72I.
} 
implores shepherds to assume their post; Peter exhorts them to this ministry because they are willing and eager to serve. Achtemeier comments on Peter's rhetoric in 5:2, writing,

“The contrast between 'not under compulsion' ( $\mu \grave{\alpha} \dot{\alpha} v \alpha \gamma \kappa \alpha \sigma \tau \tilde{\omega} \varsigma$ )

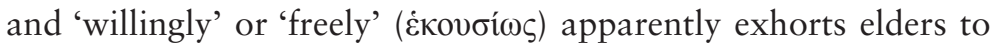
accept their responsibilities without undue coercion. . . The second antithesis qualifies the first, in that the second term $\pi \rho 0 \theta 0$ ú

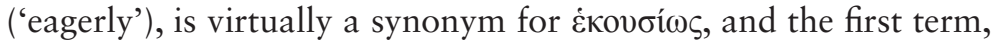
$\mu \grave{\eta} \alpha i \sigma \chi \rho о \kappa \varepsilon \rho \delta \tilde{\omega} \varsigma$ ('not in a way characterized by desire for base gain'), may be a concrete instance of the kind of compulsion to be avoided." ${ }^{6}$

As is typical in this letter, instructions to a particular party serve to instruct the larger church community. If even those who hold leadership roles are expected to humbly serve others then it follows that all members ought to follow that example. Thus, Peter instructs the younger people in the community to "subordinate"

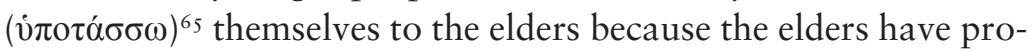
vided a compelling, imitable example. Bamyeh says that anarchy has a type of order that is not imposed, and that order means "(I) that the agreements that organize social life are voluntary in nature and (2) that whatever authority may exist is conceived of as practical rather than absolute or permanent authority." 66 That is the case here in Peter's discussion about the leadership of elders as a sensible structure for these early Christian communities, so long as they recognized that their positions were not those of domination or their right, but simply as positions that they could use to serve others, even subjugating themselves to "lesser" members of the community when necessary.

${ }^{64}$ Paul J. Achtemeier, I Peter: A Commentary on First Peter (Minneapolis: Augsburg Fortress, I996), 326.

${ }_{65}$ The importance of this particular word will be examined in the following section.

${ }^{66}$ Mohammed A. Bamyeh, Anarchy as Order: The History and Future of Civic Humanity (Lanham: Rowman \& Littlefield Publishers, 2010), 27. He further suggests that the role of these authorities is to help move subordinate members into a place where mutuality is possible. A child learns to be independent of the parent and the student learns to teach. (28) 
It is precisely because people are inclined to seek power, ${ }^{67}$ and abuse it, that an anarchist voice is necessary. Hence Peter's insistence that non-coercion and voluntary association are requisite expectations of the Christian community. Christians reject the temptation to wield coercive power, and the allure of associating too closely with folks who do; they set an example by choosing to associate with others who, like Christ, elect to serve not be served. ${ }^{6}{ }^{8}$ It may or may not prove to be an effective social strategy, though Peter assumes it will indeed influence people, but the rejection of coercive force is inseparable from Peter's larger anarchist vision.

\section{Equality of Persons}

A cursory reading of the text, specifically the Haustafel in 2:13$3: 8$, might suggest that Peter favoured forms of subjugation that were in line with the culture in which he lived, ${ }^{69}$ yet a closer reading suggests that Peter has a high regard for the equality of persons. ${ }^{70}$

The first of the three potentially problematic of exhortations in Peter's Haustafel revolves around Christians' relationship to government. It begins with the command to "submit" to governing authorities. However, an exploration of the Greek reveals that many English translations do not convey the best rendering of the text.

${ }^{67}$ Achtemeier points to the fact that "the warning against the desire for money is a regular part of [Christian] advice" (326), which is true, but it is reasonable, based on the all of 5:I-5, that similar warnings against the desire for power should also be acknowledged.

68 Matt 20:28, Mark I0:45.

69 Some scholars have suggested such a reading. See Karen H. Jobes, I Peter (Grand Rapids: Baker Academic, 2005); Simon J. Kistemaker, Exposition of the Epistles of Peter and of the Epistle of Jude (Grand Rapids: Baker, I987). Below I will articulate why such a reading is incorrect, and why an anarchistic reading of the text is more appropriate.

70 Peter seems to be following the Pauline tradition. See for example Gal. 3:27. Likewise he might be recalling his own vision about clean and unclean animals in Acts ro:9-19. 


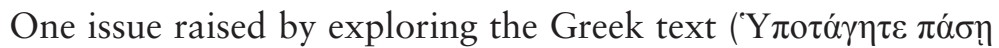

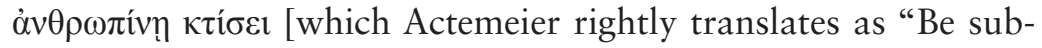
ordinate to every human creature" ${ }^{71}$ ]) is the precise meaning of the word $\kappa \tau i ́ \sigma \varepsilon 1$, which is often translated as "authority," "institution," or "ordinance." Such renderings are neither literal nor contextually appropriate. The primary meaning of $\kappa \tau i ́ \sigma ı \varsigma$ is "creation" or "creature," and the context attests to the accuracy of this sort of translation here. Achtemeier writes that "'human being,' [is] a translation to be preferred to 'human order' or 'institution,' since the latter meaning is nowhere to be found in Greek literature, and the examples that follow - emperor, governors - are human beings not institutions." ${ }^{2}$ This rendering of $\kappa \tau i$ ors suggests that Peter has an expectation that Christians willingly "submit" themselves to all people, an expectation that puts all humanity on an equal plane, undermining the claims to authority made by ruling

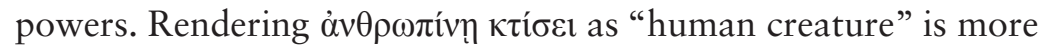
faithful to the meaning of the word $\kappa \tau i$ ir $\varsigma$, and supports the claim that Peter's concern is indeed the equality of persons. ${ }^{73}$ It challenges the prevailing arguments that this passage is primarily about submission to governing institutions, and thus disaffirms common arguments that Christians look favourably upon ruling powers. ${ }^{74}$

Another issue raised by the Greek text is the meaning of

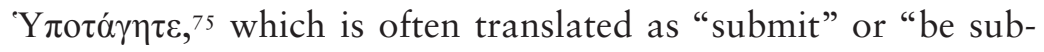
ject." It may appear that it has connotations of obedience since

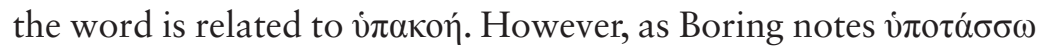
is "a broader and more flexible word," and therefore its specific meaning may be determined by context. ${ }^{76}$ Achtemeier argues that "Its meaning is closer to 'subordinate' than to 'submit' or 'obey, and advocates finding one's proper place and acting

${ }_{71}$ Achtemeier, I79.

${ }^{72}$ Ibid., I 82.

73 Unfortunately there is not space to expand this brief word study, but Elliott's own study regarding translation and meaning is helpful. See Elliott, 486 fn 92.

74 The case for this translation is strengthened by Peter's later exhortation to show proper respect to everyone (2:I7).

75 Although this is not the lexical form, I have chosen to leave the verb form here because of its imperatival force. The lexical form is i $\pi 0 \tau \alpha \dot{\sigma} \sigma \omega$.

${ }^{76}$ Boring, Io8. 
accordingly rather than calling upon one to give unquestioning obedience to whatever anyone, including governing authorities, may command." 77

Peter's exhortation follows the Pauline tradition, which calls Christians to consider others better than themselves (Phil 2:3). Boring points out that considering others better than oneself does not necessarily require obedience, nor losing one's identity. $\mathrm{He}$ writes, "What is called for here is not mindless robotic obedience or servile cowering that denies one's own identity and sense of worth, which is provided not by status in society but by rebirth and incorporation into God's saving plan for history as members of the holy people of God." ${ }^{78}$ David Lipscomb argues,

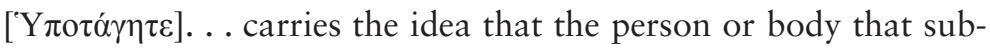
mits, is entirely distinct and separate from and in antagonism to the person or body to which it submits. The Christian then is not part of the body to which he submits, or to which he brings himself under subjection... We cannot be said to submit to ourselves, or to a body of which we are a part and parcel, and with which we are in harmony, and which we aid to conduct or manage. Submission carries the idea of antagonism and opposition which are restrained and held in abeyance. This is the relationship everywhere defined as that which connects the Christian with the governments under which they live. 79

77 Achtemeier, I82.

${ }_{78}$ Boring, Io8.

79 David Lipscomb, On Civil Government: Its Origin, Mission and Destiny and The Christian's Relation to It (Indianapolis: Doulos Christou Press, 2006), 75. The objection could be raised that Lipscomb's definition is problematic since the same word is used to describe the husband/wife relationship and the master/slave relationship. Lipscomb recognizes this and offers an extended response, part of which is quoted here. "It is argued against this, that we are commanded to submit to God - children to their parents, wives to their husbands. ... Therefore antagonism is not involved in the expression. Antagonism in all these relationships is the ground of the admonition. Were there none, there would be no need of the admonition. . . But in these relations to God, to the parents, to husbands. . . still other terms as love, honor, are added. . . [W] e are told not only to submit to God but to love him with all the soul and the mind and the body, this leads to active, hearty, soul-felt participation in carrying forward his government. So the child is commanded to love the parent, the wife her husband, and all the members of the church must have a care 
Therefore, according to Lipscomb, when Peter calls Christians to

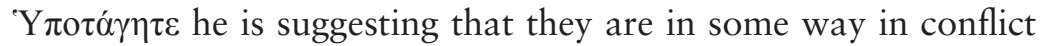
with the body to which they "submit," but this does not imply an ontological superiority on the part of the ruling body. In other words, Christians are free to submit or subordinate themselves to government because they realize their own distinct identity apart from the powers, and furthermore that they realize that this distinct identity is equally true of every other person.

The exhortation to "Be subordinate to every human creature" is directly followed by an important modifier - "on account of

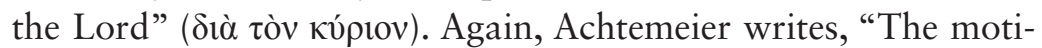
vation for such subordination, 'because of the Lord,' confirms the basis of such subordination in Christian faith. . That phrase also qualifies subordination by placing it within the larger context of obedience to God; one is not to be subordinate in matters that go counter to God's will." $8 \circ$ One cannot rightly "obey" a presumed authority for the Lord's sake if the authority is rebelling against that very Lord.

For centuries, commentators who have understood 2:I3 as a command to obey governing authorities have struggled to reconcile that interpretation with the oppositional instruction in 2:16 to "live as free men." ${ }^{81}$ Even if one understands the material in

for one another, they were to be members of one another, and to labor together for their mutual good, the advancement of their common cause, to love as brethren and be true children of God. . . But as no higher or closer relation than submission is required toward civil government, all the Christian can do in that relation, is to refrain from active antagonism and conflict, and to quietly and passively submit within the prescribed limits, but no intimation of obligation or license to participate in or in anywise fellowship and support is found" $(75-76)$.

8o Achtemeier, I82.

${ }^{8}$ Martin Luther, Commentary on Peter \& Jude, trans John Nichols Lenker. Grand Rapids: Kregel Classics, I990). For instance, Luther writes, "since ye have done all that was necessary to attain to true faith and you hold your body in subjection, let this now be your first business, to obey the civil authorities" (II6). While on the other hand, he writes, "Christians yield themselves to the control of God's Word; they have no need of civil government for their own sake" (II9). Furthermore, he claims, "Our conscience is enlightened and has become free from human ordinances and from the control which they had over us, so that we are no longer obliged to do what they have commanded under peril of our salvation" 
2:I 3 to be essentially a command to obey authorities, as some do, one still must contend with this seemingly contrary exhortation. ${ }^{82}$ Here Peter radically diverges from the Haustafel tradition because he is not concerned about upholding the hierarchies believed to hold society together. Furthermore, the Greek text (ís $\dot{\varepsilon} \lambda \varepsilon v \dot{\theta} \theta \rho \circ \mathrm{l})$ is more accurately rendered "as free [men/people]," which assumes the freedom of Peter's audience whether they live into that freedom or not. This is not to say that they are free to do whatever they please because their freedom is afforded to them as slaves to Christ, and it is to persuade others to join the Christian faith. ${ }^{83}$

Therefore, subordination is a choice, a free choice of a free human, whose allegiance is to God, not something that governments can demand. It is this freedom that ultimately strips authority from the principalities and powers because they become unneeded and unwanted by people who view all others as equal. This is the example of Jesus, who Peter points to in 2:2 I, the One with all authority who voluntarily subordinated himself to the powers who were to crucify him. ${ }^{8}$ Here Jesus demonstrated that he would rather die than take power by force, that he would rather count himself among the criminals and outcasts than the powerful elites. Jesus is the model of overcoming by subordination, the leader of this anarchist revolution of the upside-down kingdom that disarms abusive systems not by reforming them, but by offering an alternative, the alternative of a cruciform revolution

(I 20). Though it is clear that Luther difficulty with this tension, he does provide great insight for Christians dealing with the paradoxical exhortations of Peter in his statement, "For Christ's followers are to be led and ruled only be the Spirit. . . Henceforth, they are under obligation to do nothing but good to their neighbor, helping him with all they have, as Christ has helped them" (I 20).

82 See Kistemaker and/or Jobes.

83 This is a paradox that many, Christians and non-Christians, find difficult to grasp. See my argument in the essay "What About Those Men and Women Who Gave Up Their Lives so that You and I Could be Free? On Killing for Freedom" in A Faith Not Worth Fighting For (Eugene: Cascade Books, 2012), 92-94.

${ }^{8}$ Matt 26:42. Jesus subordinated himself to the governing bodies to the point of death, not because of their inherent authority, but because he was bearing witness to God's great love. 
whereby subordination to the powers in the name of God will ultimately make a spectacle of their very existence..$^{85}$

English translations diverge from the Greek text again in Verse 2:17, suggesting a different meaning than the one in Peter's original words. This verse is best translated as "Honor all [men]. Love the brotherhood. Fear God. Honor the king/emperor." Achtemeier rightly suggests that "The use of 'honor the emperor' in I Pet 2:17 as a direct parallel to 'honor all people' specifically divests the emperor of any and all trappings of divine authority and power." 86 Actually, this structure suggests an even more radical meaning because it not only "divests the emperor. . . of divine authority and power," it suggests that there is no inherent difference between even the emperor and a slave. ${ }^{87}$ Later Achtemeier moves this direction, writing, "The contrast of the first and last clauses indicates that the initial command to honor all implies such honor is not to be reserved for the mighty; no creature of God is unworthy of it, whatever his or her station in pagan society." 88

${ }^{85}$ See Col 2:I 5

${ }^{86}$ Achtemeier, I 8 I.

${ }_{87}$ This reflects Luke's comment that God is no respecter of persons (Acts Iо:34). If Christians are to follow that example then they too must refuse to show favor.

${ }^{88}$ Achtemeier, I 88. Peter of course finds himself in a difficult place where he must simultaneously instruct his readers about the anti-hierarchical nature of the Kingdom of God, while not drawing unnecessary attention to his words from those who are looking for reasons to attack Christians, as well as attempting to redefine concepts of honor and shame for his readers. Peter's letter serves a paraenetic function, in that it offers moral exhortations intended to socialize converts to this new religion (Troy W. Martin, Metaphor and Composition in I Peter. [Atlanta: Scholars Press, I992], I03-II8). Paraenesis, and its resulting socialization, in the hierarchical Greco-Roman society was intended to cause one to live in such a way that "one could attain $\delta$ ó $\xi \alpha$ (glory)" (Martin, Io8). For Peter's audience, however, in attempting to follow the teachings of Jesus they have been maligned, scorned, and persecuted. According to Martin, "This problem sets up the rhetorical situation for the author of I Peter and explains the unique paraenetic feature of eschatology. . . in this letter .... The author of I Peter has resorted to eschatological ideas in his paranaesis to resolve this problem of a non-realization of $\delta$ ' $\xi \alpha$ (Martin, I I I-I I2). Martin is largely correct, but Peter doesn't so much "resort" to using eschatological arguments as much he simply continues in the tradition of Jesus' own teaching, perhaps recalling Jesus' words that his 
The individual sections of this pericope each suggest a reading sympathetic to an anarchistic equality of persons under and before God. The same is true of the whole pericope, 2:I3-I7. Achtemeier writes:

The inclusio formed by the two imperatives that begin ('Y 'be subordinate') and end ( $\tau \mu \tilde{\alpha} \tau \varepsilon$, 'honor') the passage, and by the opening and closing references to the emperor, shows it to be a careful literary composition. One must therefore pay attention to the deliberate limitations placed here on the status of civil government: the emperor is a 'human creature' to whom subordination is due as an example of general subordination on the part of Christians within civil society. ${ }^{89}$

Peter's construction challenges notions that Christians were enemies of the empire, while simultaneously subverting it by giving each person equal respect.

A brief caveat is necessary here to explain the importance of assessing the structure of a text in the field of biblical exegesis. In an attempt to understand the text inductively, that is to attempt to understand the text on its own grounds rather than imposing meaning on the text, exegetes often look for structural relationships in the text that may make authorial intent more apparent. One of the structures seen often in the biblical text is called inclusio. "Inclusio is the repetition of words of phrases at the beginning and end of a unit, thus creating a bracket effect. At the boundaries inclusio establishes the main thought of the book (passage), pointing to the essential concern of the book (or passage). One should note the relationship between these bracketing statements and the intervening material in order to identify the semantic relationship

followers would indeed experience persecution for being his disciples, and later Paul's words that it was after Jesus' suffering and shame that Jesus received the joy of glory (e.g. Phil 2:6-I I, Heb I 2:2). Thus, Peter is saying precisely what he means, but only one who is in on the redefinition of terms in the Christian tradition would understand this reappropriation. Peter uses the common social framework of glory/honor and shame, but reinterprets the concepts through the lens of the uniquely Christian assertion that suffering comes before glory, and glory only comes, at least in fullness, when God resurrects and redeems the faithful.

89 Achtemeier, I80. 
with which an inclusio is used." 90 In other words, this is simply a form of parallelism, which is commonly used in many types of literature in order to emphasize a given point or to highlight the similarities in a variety of connected clauses.

"Thus the bracketing statement is a general claim that is spelled out, or particularized, in the intervening material," note Bauer and Traina. ${ }^{9 \mathrm{I}}$ In this case, Peter makes the general statements regarding subordination and honour, but spells out the parameters regarding the way in which his readers are to submit to and honour others, including his seemingly contradictory claim that they are to live as free people. This pericope seems to be a paradox in that by honouring the authorities they are shamed. According to Peter in the verse that precedes this pericope, the contrast of the good behaviour of Jesus' disciples, largely epitomized by enduring unjust suffering for Christ's sake, with the idolatrous, self-serving behaviour of the powers, will expose the corruption and injustice meted out by the imposturous and rebellious powers of this world.

While the focus of this analysis has been primarily on the rhetorical structure of this pericope, the brief segues into theological and social issues strengthen the claims regarding Peter's shrewd composition. Like other writers who find themselves vulnerable because they are at odds with a society's values, Peter employs cunning rhetorical and theological moves that those socialized into early Christianity could understand and appreciate while those outside this "chosen people" (2:9) would not find immediately threatening. The following section of exhortations directed at slaves, then wives and husbands should further illumine the sort of double meaning potentially bound up in Peter's letter by exposing more of the ways in which different inferences might be made by those inside church and those on the outside. With this in mind it is possible to see the subversive nature of Peter's next set of instructions.

${ }^{90}$ David R. Bauer and Robert A. Traina, Inductive Bible Study: A Comprehensive guide to the Practice of Hermeneutics (Grand Rapids: Baker Academic, 20II), II 7.

91 Ibid, I 18 . 
Peter moves into exhortations directed at slaves, then wives and husbands. Though specific parties are addressed, Peter never loses sight of the whole community. His instructions to these specific parties serves a double purpose, to help these particular persons find their place as individual moral agents and bearers of the Imago Dei, and to use them as examples of Christlikeness. "Since 2:13-3:7 doesn't cover all cases and classes, instructions to slaves and wives are to be taken as illustrative. . The whole community is to learn from what is said to slaves and wives." ${ }^{92}$

\section{On slaves}

Again, Peter's modified use of the Haustafel dignifies slaves by assuming their moral agency, yet it is disturbing to modern readers that he takes no umbrage with slavery itself. However, a closer reading of the text suggests that Peter is merely taking a more calculated and ultimately subversive approach. By revisiting themes

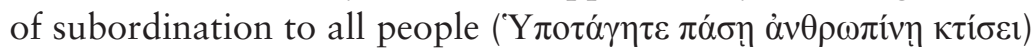
and being as free people, then setting slaves up as examples to the rest of the Christian community, and directly connecting them with Christ, Peter turns the social order on its head, a reality already coming to fruition in early Christian communities.

Two relevant clauses point readers back to Peter's previous discussion. First, Peter uses the word "subordinate," in this case

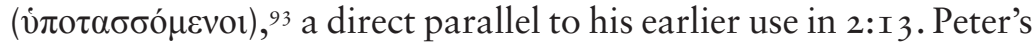
use of "subordinate" to slaves here is a particularization of his instruction for all Christians to do so. Second, Peter points back to his discussion about the freedom of all Christians, including those in slavery, as those who choose to live as "God's slaves" ( $\theta \varepsilon$ ov $\delta$ oṽ $\lambda$ or). As Boring remarks, "all Christians are free, all are slaves. As those already freed and accepted before God, their identity does not depend on the social status others attribute to them." 94

92 Boring, I07.

93 The lexical form is i்o

94 Ibid., I I I. It should be noted however that some ancient writers like Seneca recognized slaves as having the same inherent value as all other humans, but he still supported slavery so long as masters treated their slaves well. 
Peter cunningly subverts social values, asserting the equality of persons. As Joel Green writes, “[I]t is obvious that Peter's theological perspective (particularly his identification of his Christian audience, including slaves [v. I7], as 'free persons' [v. I6], his emphasis on 'honoring all persons,' including slaves, and his specific address to slaves as moral agents [v. I 8]) must trigger the unraveling of the institution of slavery - at least insofar as this institution rested on arguments from inherent nature and incarnate status in the Greco-Roman world." 95

Peter not only dignifies slaves by addressing them as moral agents, he sets them up as examples to the rest of the Christian community. This at once serves to uplift slaves and call those in higher social classes to seek a certain downward mobility, thus moving closer to a society where all people not only have theoretical, but realized, equality.

It is noteworthy that "Romans reacted negatively when Jewish and Christian slaves - the first group to do so - rejected the worship of their masters' gods, insisting on an exclusive worship of their own God" ${ }^{6}$ because these slaves are examples of godliness in the face of potentially awful consequences. Those who otherwise have little or no power are empowered to lead the rest of the Christian community by example. ${ }^{97}$ This means that other Christians are not to subjugate those in slavery, but to look to them as exemplars of Christian discipleship.

Most important is the fact that, as Keener notes, "Although ancient society was very status-conscious and associated power with greatness, Peter identifies Christ with unjustly treated slaves." 98 This comparison undermines conventional ways of thinking and challenges readers to live the values of Jesus' upside-down kingdom. That is to say, by comparing Christ to slaves, Peter dignifies lowliness and exhorts his readers to take on servant roles because they are free to do so in Christ. In this way, it is important to note

95 Green, 79.

${ }_{96}$ Balch, 74 .

${ }_{97}$ It is at least conceivable that slaves could be elders in the early church, and as the discussion earlier about shepherds suggests they would be potentially great candidates.

${ }_{98}$ Keener, 7 I 5 . 
that the particulars of a slave's experience are at the fore, and thus the suffering of the slave is not meant to be downplayed. There is no sort of "All Lives Matter" move being made here. Peter clarifies that "Slave Lives Matter."

\section{On Wives and Husbands}

Peter's instructions to wives carry some complex socio-cultural baggage, but they, along with instructions to husbands, offer insight into understanding the equality of persons in Peter's thought. Women in much of the ancient world had little power and were often viewed as property, and agents of seduction leading men astray from their religious/societal duties. ${ }^{99}$

The women Peter addresses had already broken with tradition choosing to worship their own God instead of their husbands' gods, something that Peter unequivocally commends, exhorting wives to lead their husbands to Christian belief. This is a reversal of the typical expectations, stated by Plutarch: "A wife ought not make friends of her own, but to enjoy her husband's friends in common with him. The gods are the first and most important friends. Therefore it is becoming for a wife to worship and know only the gods that her husband believes in, and to shut the front door tight upon all queer rituals and outlandish superstitions. For with no god do stealthy and secret rites performed by a woman find any favour." ${ }^{\circ \circ 0}$

For the wives Peter is addressing there is no expectation that women are required to follow their husbands into any religion, but that women had the power to lead their husbands into worship of the true God. Likewise, Peter's instruction to wives necessitates

99 The fact that Peter feels compelled to address wives with specific instructions to subordinate (vं (3:I), a practice already expected of women in Greco-Roman society, suggests that these women had already begun embracing the freedom found in Christ, though it seems that they may have been choosing to use that freedom in unwise ways.

זo0 Found in Balch, 85 . 
that their worship not be done in secret, and more importantly that God would indeed find favour in their worship. ${ }^{\text {Ior }}$

Some might point to Peter's use of Sarah as an example of wifely obedience to undermine the above interpretation, but one need only look briefly at the story Peter is referencing, both in its biblical and extrabiblical contexts, to see that Sarah and Abraham's relationship was more complicated than might initially appear. Peter could be referring to Gen I8:I2, which shows "Sarah was hardly the paradigm of the servile housewife, but was laughing out loud." ${ }_{102}$ Rather than being obedient to Abraham, she was in fact sometimes disrespectful. "Moreover, in the relevant material in Genesis, it is easier to find evidence that Abraham obeyed Sarah more than the other way around." "ㅇ On the other hand, Peter also says that Sarah called Abraham "Lord," which could suggest that husbands may rightly subjugate their wives. However, "[Lord] was not an unusual expression on the lips of Sarah, but was the way in which all women of the period referred to their husbands (probably with as little reflection on it as a modern woman gives to the term 'husband)." ${ }^{\text {IO4 }}$ My wife, for example, refers to me as a husband to others, but does occasionally call me husband directly as well.

ror This perhaps reflects Peter's more general exhortation that Christians live such good lives among their pagan counterparts that the pagans would see these good works and glorify God (2:I2).

${ }_{102}$ Boring, I25-I 26.

${ }^{103}$ Green, 96. Green remarks, in footnote 79, that in Genesis God actually tells Abraham to obey Sarah at one point, but the reverse is never seen in Genesis.

${ }^{104}$ Peter H. Davids, The First Epistle of Peter (Grand Rapids: Eerdmans, I990), I20-I2I. In fact Davids contends elsewhere that, "bible translations divide over whether to translate this term according to its use in I Peter or within the context of Genesis. Like the NRSV, the NAB translates the term contextually as "my husband." The NKJV follows the traditional AV rendering of "my lord." The NIV has "my master" with the alternative "husband" in a note. The NLT compromises with "my mastermy husband." Davids, "A Silent Witness in Marriage: I Peter 3:I-7" in Discovering Biblical Equality: Complementarily without Hierarchy edited by Ronald W. Pierce and Rebecca Merrill Groothuis with Gordon D. Fee (Downers Grove: IVP Academic, 2005), 23 I. 
However, it could very well be the case that Peter does not, primarily at least, have the Genesis text in mind, but extrabiblical stories familiar to the Jewish people. It seems that commentators around Peter's time were actually discussing the significance of Abraham and Sarah's interactions. ${ }^{\text {Ios }}$ Peter, once again, might be "splitting the difference" inasmuch as his reliance on the Genesis text would likely lead to one conclusion, but his reliance on the extra-biblical literature would point to a different conclusion. Perhaps he has both in mind, as this essay has shown, was his general way of helping Christians avoid persecution while eroding away the very systems that were the source of that persecution.

Peter's reference is not to convince wives of their inferiority, but rather to encourage them to choose subordination as a witness to the God who is faithful to make all things right. Furthermore, “These [including Sarah] were 'holy women,' not because of their specific moral virtue, but because they were heroines of the Scriptures.” ${ }^{106}$ Sarah's particular heroism, as it relates to Peter's purposes, was in the hope she placed in God, specifically as an alien and stranger in a foreign land.

Perhaps Peter uses Sarah to poke fun at unwitting pagans who believed that the natural order required wives to do what their husbands command. At first glimpse, they would have likely seen Peter's words as essentially endorsing Greco-Roman values, but those familiar with the story of Sarah would be inclined to see her as a more complex example of faithful hope rather than simply wifely obedience. Peter has in view a people who would put their hope in God, exhorting them to treat all people with reverent dignity.

Likewise, calling wives the weaker vessel is sometimes viewed as an ontological statement about women's strength of character, emotional stability, or intended place in society and marriage. ${ }^{107}$

${ }^{105}$ Davids, “A Silent Witness," 233.

106 Ibid., I I9.

107 See for example, Wayne Grudem, I Peter (Grand Rapids: Eerdmans, 2002), I43-I45. Grudem argues that women are "weaker vessels" in at least three ways. First, he says they have less physical strength than men. Second, according to Grudem, women are weaker in that they have less authority in marriage. Third, he argues, women are more emotionally vulnerable, which he says is a weakness that can also be a strength. Also, 
This view fails on at least two counts. First, and perhaps most notably, the reference to females as "weaker" directly follows six full verses that speak specifically about the strength of character required of Christian women, and the behaviours expected from women as fully human moral agents. ${ }^{\text {108 }}$

Second, the most contextually appropriate reading of the text shows Peter's awareness of the ways in which women were vulnerable in his readers' context. As Jean Bethke Elshtain writes, "Human beings are soft-shelled creatures. All bodies are fragile. But some bodies, in some circumstances are more vulnerable than others." ${ }^{\circ}$ o9 Peter reminds husbands that this is the situation for their wives in the patriarchal Greco-Roman world. These wives are more susceptible to abuse in the male-dominated culture, and therefore Christian husbands have a responsibility to counter these societal norms by treating their wives as equal heirs to all that God offers.

For Peter, the point of Christians choosing to live into the freedom of Christ is that they live holy lives that others find strangely compelling. As people adopt Christianity, the expectation is that they treat all others equitably as Jesus did. Peter is proposing a social strategy whereby Christians would move the world toward an embrace of anarchist principles, perhaps the most important of which is the equality of persons. ${ }^{\text {IIO }}$ In short, "The servant-ethic of

see Martin Luther Commentary on Peter and Jude (Grand Rapids: Kregel Classics, I990), I40. Luther writes that "the wife is weaker bodily, as well as more timid and more easily dispirited." Davids notes, I23, that it was common in the Greek and Hebrew world for women to be viewed as "weaker in mind or morally inferior" by citing Plato (Leg 6.78 Ib) and noting that other places in scripture use similar wording to talk generally about human moral failings (Rom 5:6) and an irresolute conscience (I Cor 8:7-II; Rom I4:I).

${ }^{108}$ See Davids, I23.

ro9 Jean Bethke Elshtain, "The Equality of Persons and the Culture of Rights," University of St. Thomas Law Journal: Vol. I: Iss. I. (2003), 5. Available at: http://ir.stthomas.edu/ustlj/volı/iss I/2

по There is no doubt that equality of persons could, by itself, fall under progressive or Marxists ideologies, but the way I believe Peter is using it is thoroughly anarchist because his vision involves no coercion or benevolent dictator or government program that will bring about his desired outcome. Rather, Peter proposes a society where people by their own 
I Peter, then, is strategic. In essence, it seeks to turn enemies into friends.” ${ }_{\text {II }}$

\section{Subverting the Powers}

Hopefully, the subversive nature and power of non-coercion, voluntary association, and the equality of persons has begun to become apparent in this overview of I Peter. That being the case, it is pertinent to only highlight the points of contact that these themes make with the Petrine message of subversion of the powers.

When one experiences unjust suffering, oppression unleashed by the powers, there is a temptation to lash out against those forces or to rebel in hopes of establishing a new order. This approach simply perpetuates the power struggles, shifting the power from one person or group to another.

Peter offers no such option to Christians. He suggests an alternative way of being in the world. He writes:

Above all, love each other deeply, because love covers over a multitude of sins. Offer hospitality to one another without grumbling. Each of you should use whatever gift you have received to serve others, as faithful stewards of God's grace in its various forms. If anyone speaks, they should do so as one who speaks the very words of God. If anyone serves, they should do so with the strength God provides, so that in all things God may be praised through Jesus Christ. To him be the glory and the power for ever and ever. Amen $(4: 8-$ I I $) .{ }^{\text {II } 2}$

free choice extend a hand of friendship to enemies precisely because they have their own free moral agency and can choose to use it in this way. Nor is Peter's concern primarily economic; he is simply articulating the larger NT vision that in the Kingdom of God there will not be divisions based on race, gender, or social status, but all people will be invited to participate in the community as they choose.

in Carter, 89.

II Much could be drawn out from this specific passage, but one of the most compelling arguments for the power of subversion Peter has in mind one might focus on his call to hospitality. See Christine D. Pohl, Making Room: Recovering Hospitality as a Christian Tradition (Grand Rapids: Eerdmans, I999). Pohl writes, "Although we often think of hospitality as a tame and pleasant practice, Christian hospitality has always had a subversive countercultural dimension. 'Hospitality is resistance,' as one 
This is the alternative Peter offers for subverting the powers while avoiding being drawn into them. It is an important word because as Ellul writes, "When the church has been seduced by the ruling classes, becoming a power or being obsessed with politics, this is tantamount to its possession by the prince of this world himself." ${ }_{\text {II3 }}$

First Peter is a manifesto of sorts in which Christianity is set against the powers. These powers, the ones upholding the hierarchies Christ came to destroy, are undermined by this band of aliens and strangers who claim Jesus is Lord. Peter's epistle is an archetype of Ellul's statement that "Biblically, love is the way, not violence. . . Not using violence against those in power does not mean doing nothing. . Christianity means a rejection of power and a fight against it. . . There remains the anarchism which acts by means of persuasion, by the creation of small groups and networks, denouncing falsehood and oppression, aiming at a true overturning of authorities of all kinds as people at the bottom speak and organize themselves." ${ }^{\prime \prime 4}$ Alexandre Christoyannopoulos, drawing from Peter Brock writes, "the state may be valid for nonChristians, but if 'all truly followed in Christ's footsteps it would wither away.' God uses the state in his ordering of the cosmos only because his commandments for a peaceful and just society are not being followed." "Is Thus, the church's witness of subordination is intended to draw people into the Christian faith which ought to have the side effect of the dissolution of oppressive power structures.

Peter's letter maintains that Christians subvert the powers not by violence, or rebellious revolution, but through the faithful witness of righteous suffering. Non-coercion and voluntary association, and the equality of persons are part and parcel of such a witness. Each calls into question the legitimacy of the powers, and

Catholic Worker observed. Especially when the larger society disregards or dishonors certain persons, small acts of respect and welcome are potent far beyond themselves. They point to a different system of valuing and an alternate model of relationships" (6I).

${ }^{\text {II } 3}$ Jacques Ellul, The Subversion of Christianity (Grand Rapids: Eerdmans, I986), I 80 .

${ }^{I} 4$ Ellul, A\&C, I3-I4.

is Christoyannopoulos, I 53-I 54 . 
exposes their sinfulness, challenging each person to glorify God rather than self.

\section{Social Location and Christian Witness}

Peter is making the radical claim that it is not the powerful, the violent, the coercive, nor the privileged who wield true influence in the world. ${ }^{116}$ It is the ones who are humble, by choice or by circumstance, the ones who take up crosses upon their shoulders, who are able to bear witness to the true, eschatological reality that the powers, even death itself, have been overcome by Jesus. ${ }^{117}$ Rather than pursuing power, for Green, "Christians should expect to be treated as those who are powerless. . . knowing, however, that their appropriate conduct would have a redemptive effect akin to that of Jesus."

As Boring puts it, "Throughout [I Peter], the emphasis is on mission, not on submission. As in the example of Christ (2:2 I25), submission is for the sake of mission." "II9 The mission is taken up voluntarily with a purpose in mind, not because the social order demands it, nor because one group is necessarily inferior or supposed to be subservient to another. The message here is that by choosing submission Christians follow the example of Christ. Speaking to the disenfranchised, Peter honours their contributions to the Christian mission and shames the powerful who would impede that mission. He also suggests that it is not the powerful of this world who are most like Christ, but those who find their place in humble, seemingly powerless, service to others. Therefore, Peter seems to be arguing that Christians effect change in the world, not by using power over others, but by bearing witness to the eschatological hope and truth of Jesus. Near the end of

${ }^{116}$ More evidence of Peter's concern with social location can be seen in his address to wives regarding their dress. Peter argues against the notion that it is displays of wealth or beauty that show one's value. Davids writes, “[Peter's] critique would apply mainly to upper-class women who could afford more than the simplest dress (and perhaps to the aspirations of other women). Thus it is a critique of the whole culture" (I I7-I I 8).

I17 See Col 2:I 5 .

II8 Green, 72.

I19 Boring, I 3 . 
his specific instructions to the congregations regarding righteous subordination and its effects, Peter writes: "Humble yourselves, therefore, under God's mighty hand, that he may lift you up in due time" (4:6).

Peter's vision of Christian witness was not of rebellion, but that they model a different society, one not predicated on hierarchies and coercion even as they choose to subversively subordinate themselves to these forces that are already present, but on loving relationships where each person honours the dignity of others. Two millennia after it was written, Peter's epistle still offers an implicit yet compelling vision for an alternative society, a society that embraces anarchist values of non-coercion, voluntary association, and the equality of persons all as a way to subvert the powers intent on maintaining their perceived control of the world. Paradoxically, it is not the powers that have power over the world's destiny, but the One and ones who choose humble subordination that declare the triumph of love.

\section{References}

Achtemeier, Paul J. I Peter: A Commentary on First Peter. Minneapolis: Augsburg Fortress, I996.

Amster, Randall. Anarchism Today. Santa Barbara: Praeger, 20 I 2.

Balch, David L. Let Wives Be Submissive: The Domestic Code in I Peter. Chico: Scholars Press, I98I.

Bamyeh, Mohammed A. Anarchy as Order: The History and Future of Civic Humanity. Lanham: Rowman \& Littlefield Publishers, 20го.

Bartley, Jonathan. Faith and Politics After Christendom: The Church as a Movement for Anarchy. Milton Keynes: Paternoster Press, 2006.

Bauer, David R. and Robert A. Traina. Inductive Bible Study: A Comprehensive guide to the Practice of Hermeneutics. Grand Rapids: Baker Academic, 20I I.

Boring, M. Eugene. I Peter. Nashville: Abingdon, I999.

Barringer, Justin Bronson. "What About Those Men and Women Who Gave Up Their Lives so that You and I Could be Free? On 
Killing for Freedom.” A Faith Not Worth Fighting For. Tripp York and Justin Bronson Barringer eds. Eugene: Cascade Books, 20 I 2.

Carter, Philippa. The Servant-Ethic of the New Testament. New York: Peter Lang, I997.

Cavanaugh, William. The Myth of Religious Violence: Secular Ideology and the Roots of Modern Conflict. Oxford: Oxford UP, 2009.

Christoyannopoulos, Alexandre. Christian Anarchism: A Political Commentary on the Gospel. Exeter: Imprint Academic, $20 \mathrm{II}$.

Clark, John P. "What is Anarchism?" J. Roland Pennock and John W. Chapman eds., Anarchism: Nomos XIX. New York: New York University Press, I978.

Davids, Peter H. “A Silent Witness in Marriage.” Discovering Biblical Equality. Ronald W. Pierce and Rebecca Merrill Groothuis eds. Downers Grove: IVP Academic, 2005.

- Davids, Peter H. The First Epistle of Peter. Grand Rapids: Eerdmans, I990.

Eller, Vernard. Christian Anarchy: Jesus' Primacy Over the Powers. Grand Rapids: Eerdmans, I987.

Elliott, John. I Peter: A New Translation with Introduction and Commentary. Anchor Bible Commentary. New York: Anchor/ Doubleday, 2000.

Elshtain, Jean Bethke. "The Equality of Persons and the Culture of Rights." University of St. Thomas Law Journal, Vol. I: Iss. I. (2003). http://ir.stthomas.edu/ustlj/volı/issı/2

Ellul, Jacques. Anarchy and Christianity. Grand Rapids: Eerdmans, I99I.

- The Subversion of Christianity. Grand Rapids: Eerdmans, I986.

Fiorenza, Elisabeth Schüssler. Bread Not Stone: The Challenge of Feminist Biblical Interpretation. Boston: Beacon Press, I995.

Ferguson, Everett. The Church of Christ: A Biblical Ecclesiology for Today. Grand Rapids: Eerdmans, 1996. 
Goldman, Emma. "Anarchism: What It Really Stands For." Anarchism and Other Essays. New York: Mother Earth Publishing Association, I9I0. http://dwardmac.pitzer.edu/anarchist_archives/ goldman/aando/anarchism.html

Goosen, Rachel Waltner. "'Defanging the Beast': Mennonite Responses to John Howard Yoder's Sexual Abuse.” Mennonite Quarterly Review No. 89, January 20I5. http://www.bishop-accountability.org/news5/20I 5_OI_Goossen_Defanging_the_Beast. pdf

Green, Joel B. I Peter. Grand Rapids: Eerdmans, 2007.

Grudem, Wayne. I Peter. Grand Rapids: Eerdmans, 2002.

Horrell, David G. "Between Conformity and Resistance: Beyond the Balch-Elliot Debate Towards a Postcolonial Reading of First Peter." Robert L. Webb and Betsy Bauman-Martin eds. Reading First Peter with New Eyes: Methodological Reassessments of the Letter of First Peter. New York: T\&T Clark: 2007.

Jobes, Karen H. I Peter. Grand Rapids: Baker Academic, 2005.

Keener, Craig. The IVP Bible Background Commentary: New Testament. Downers Grove: InterVarsity, I993.

Kistemaker, Simon J. Exposition of the Epistles of Peter and of the Epistle of Jude. Grand Rapids: Baker, 1987.

Kropotkin, Peter. Marshall Shatz ed. Conquest of Bread and Other Writings. Cambridge: Cambridge University Press, I995.

Lipscomb, David. On Civil Government: Its Origin, Mission and Destiny and The Christian's Relation to It. Indianapolis: Doulos Christou Press, 2006.

Luther, Martin. Commentary on Peter \& Jude. John Nichols Lenker trans. Grand Rapids: Kregel Classics, I990.

Marshall, Peter. Demanding the Impossible: A History of Anarchism. New York: Harper Perenial, 2008.

Martin, Troy W. Metaphor and Composition in I Peter. Atlanta: Scholars Press, I992.

Miller, David. Anarchism. London: JM Dent, I984. 
Pohl, Christine D. Making Room: Recovering Hospitality as a Christian Tradition. Grand Rapids: Eerdmans, I999.

Tolstoy, Leo. “On Anarchy.” Pamphlets Translated from the Russian. https://archive.org/stream/pamphletstranslootolsgoog\#page/n250/ mode/rup.

Walter, Nicolas "About Anarchy." Howard J. Ehrlich, Carol Erlich, David DeLeon, and Glenda Morris eds., Reinventing Anarchy: What Are Anarchists Thinking These Days?. London: Routledge \& Kegan Paul, I979.

Yoder, John Howard. The Politics of Jesus. Grand Rapids: Eerdmans, I994. 